\title{
WAS EVANGELICALISM CREATED BY THE ENLIGHTENMENT?
}

\author{
Garry J. Williams
}

\begin{abstract}
Summary
David Bebbington has published a number of influential works arguing that Evangelicalism was created by the Enlightenment. He claims that the new and distinctively Evangelical activism of the 1730s was only possible because of a novel doctrine of assurance. This doctrine was in turn born of the dependence of John Wesley and Jonathan Edwards on Enlightenment epistemology. The following article questions this claim and thus seeks to re-open the case for the identity of Evangelicalism with the Reformation and Puritanism.
\end{abstract}

\section{Introduction}

The task of identifying the enduring essence of particular religious movements is one of the perennial challenges faced by the church historian. From time to time brave individuals propose definitions which claim to function sufficiently well to allow the discussion of a particular movement to continue, or even to take a significant step forward. With similar frequency, gainsayers protest that the movement in question is actually undefinable and should in fact no longer be thought of as a movement. The debate grinds on, the whole process resembling a war in the paralysis of attrition, while every so often someone sitting in safety far from the front-lines wins a prize for writing the best summary of the struggle so far. Notorious examples abound. In the Second Century it might be Gnosticism, in the Sixteenth, Radicalism; both have been defined and redefined, and both have been denied. Gnosticism, we are told, needs to be re-thought out of existence, the Radical Reformation scarcely deserves the title. Probably each century has its own example. In the Eighteenth Century, it is Evangelicalism. 


\section{The Definition of Evangelicalism}

One of the more successful of such historical definitions has been the account of Evangelicalism offered by David Bebbington in Evangelicalism in Modern Britain (1989). This history of Evangelicalism was rightly hailed for its liveliness, breadth, and light touch in deploying an impressive range of detailed evidence from primary sources. Bebbington defines the four essential Evangelical characteristics as conversionism, activism, biblicism, and crucicentrism. ${ }^{1}$ His definition has been widely accepted. It is almost true that wherever one turns in recent writing on Evangelicalism in its British forms these characteristics are employed. Writing in 1994, Derek Tidball notes that the fourfold definition 'has quickly established itself as near to a consensus as we might ever expect to reach'.2 A recent transatlantic study notes that even though Bebbington was writing about British history, his categories have been found to have 'a definitional virtue' which has carried them beyond Britain to America. ${ }^{3}$ In a comparative treatment Bebbington himself has stated that 'the defining characteristics were the same in Britain and the United States'. ${ }^{4}$ Some voices have been raised in dissent at different levels. In his personal sketch of the history of Evangelicalism from 1935 to 1995, Oliver Barclay argues that the four terms need to be re-ordered and given more precise definition. ${ }^{5}$ D.A. Carson raises various problems, including the fact that the characteristics emphasise Evangelical distinctives at the expense of those credal areas on which Evangelicals may agree with others. ${ }^{6}$ Further criticisms have been, and no doubt will be made of the definition qua definition.

1 D.W. Bebbington, Evangelicalism in Modern Britain: A History from the 1730s to the 1980s (London: Unwin Hyman, 1989), 1-17. This is Bebbington's most significant work on the subject and is the basis of his other presentations of the same argument, to which reference will be made below where appropriate.

2 D.J. Tidball, Who Are The Evangelicals? (London: Marshall Pickering, 1994), 14.

3 R.H. Krapohl \& C.H. Lippy, The Evangelicals: A Historical, Thematic, and Biographical Guide (Westport, CT: Greenwood, 1999), 7. Though it is important to note that the American discussion of Evangelicalism is capable of proceeding without reference to Bebbington, e.g. G. Dorrien, The Remaking of Evangelical Theology (Louisville, KY: Westminster John Knox, 1998).

4 'Evangelicalism in Modern Britain and America', in Amazing Grace: Evangelicalism in Australia, Britain, Canada, and the United States, ed. G.A Rawlyk \& M.A. Noll (Grand Rapids, Michigan: Baker, 1993), 183-212 (185).

5 O. Barclay, Evangelicalism in Britain: 1935-1995 (Leicester: IVP, 1997), 10 12.

6 D.A. Carson, The Gagging of God: Christianity Confronts Pluralism (Leicester: Apollos, 1996), 449-51. 


\section{The Enlightenment Origins of Evangelicalism}

Here, however, my interest is not so much in the defining characteristics themselves as in the way in which Bebbington uses them to date the origins of Evangelicalism (though I will raise some broad questions about his account of activism below). While earlier writers such as J.C. Ryle and E.J. Poole-Connor turned to the Reformers or even to John Wyclif for their starting point for Evangelical history, Bebbington opens his book with the declaration that 'Evangelical religion is a popular Protestant movement that has existed in Britain since the 1730 s' $^{7}$ He grants that the movement did not emerge ex nihilo, but it was nonetheless something that had not been seen before: 'There was much continuity with earlier Protestant traditions, but [...] Evangelicalism was a new phenomenon of the eighteenth century'. ${ }^{8}$ Without wanting to deny the many good reasons for which Bebbington's treatment has proved seminal, I will seek to show that the case made for this dating does not hold. It is not my purpose here to propose an alternative dating; I am seeking simply to reopen the case for seeing Puritanism and the Reformation as themselves authentically Evangelical movements.

In substantiating his opening declaration, Bebbington offers a distinctive detailed argument for the origins of Evangelicalism. He dates the origins to the 1730 s because he holds that the movement was a child of the Enlightenment. The evidence here rests on the role which the second characteristic plays:

The activism of the Evangelical movement sprang from its strong teaching on assurance. That, in turn, was a product of the confidence of the new age about the validity of experience. The Evangelical version of Protestantism was created by the Enlightenment. 9

This is a telling argument, since it shows that despite the fourfold definition, the decisive emphasis for Bebbington is on the single feature of activism. As he himself allows, 'Three characteristic marks of Evangelicalism, conversionism, biblicism and crucicentrism, had been as much a part of Puritanism as they were of Methodism'. ${ }^{10}$ It is

7 Evangelicalism in Modern Britain, 1. For examples of the earlier dating see E.J. Poole-Connor, Evangelicalism in England (London: Fellowship of Independent Evangelical Churches, 1951) which begins in the Fifteenth Century, and J.C. Ryle, Knots Untied (London: William Hunt, 1874) where Ryle repeatedly treats a host of Reformation writers as Evangelicals.

8 Evangelicalism in Modern Britain, 1.

9 Evangelicalism in Modern Britain, 74.

10 Evangelicalism in Modern Britain, 35. 
activism which marks the step from the Puritans to the Evangelicals. The link from activism to the Enlightenment is made by the Evangelical doctrine of assurance. Bebbington explains that 'the dynamism of the Evangelical movement was possible only because its adherents were assured in their faith' ${ }^{11}$ Earlier Protestants had been concerned with assurance, but now 'the content of the doctrine was transformed'. ${ }^{12}$ The novelty lay in the expected timing and ground of an individual's sense of assurance:

Whereas the Puritans had held that assurance is rare, late and the fruit of struggle in the experience of believers, the Evangelicals believed it to be general, normally given at conversion and the result of simple acceptance of the gift of God. ${ }^{13}$

The final phrase here is significant: all that was needed for assurance from the start of the Christian life was 'simple acceptance of the gift of God'. Bebbington paints a picture in which this early assurance arising from simple acceptance stands in sharp contrast to the Puritan emphasis on late assurance arising from close self-examination. In the Puritan context, 'the ignorance of the believer about his future destiny would drive him to scrutinise himself for signs of grace'. ${ }^{14}$ The Puritans even had lists of the signs of grace for which the believer should search. Against this picture of introspective gloom, Bebbington depicts the Evangelical position as one of robust confidence in which early assurance is the norm. There might, he states, be a momentary self-examination, but 'the process was, as it were, non-recurrent: it was expected that the verdict would be favourable'.15 Selfexamination was for the Puritans, 'Eighteenth-century Evangelicals, by contrast, turned their attention from their own state to the message that was to be proclaimed.' 16

Bebbington precisely identifies the 1734-35 revival in Northampton under Jonathan Edwards as the point at which this shift took place. From here it is a small step from the confidence of Edwards in assuring converts back to the Enlightenment origins of Evangelicalism:

How could he be so bold? It was because he was far more confident than his Puritan forefathers of the powers of human knowledge. A person, he held,

11 Evangelicalism in Modern Britain, 42.

12 Evangelicalism in Modern Britain, 43.

13 Evangelicalism in Modern Britain, 43.

14 Evangelicalism in Modern Britain, 43

15 Evangelicalism in Modern Britain, 46.

16 D.W. Bebbington, 'Revival and Enlightenment in Eighteenth-Century England', in Modern Christian Revivals, ed. E.L. Blumhofer \& R. Balmer (Urbana/Chicago: University of Illinois, 1993), 17-41 (21). 
can receive a firm understanding of spiritual things through a 'new sense' which is as real as sight or smell. ${ }^{17}$

Edwards reached this epistemic confidence because he drank deeply from the waters of the English Enlightenment, in particular from the works of John Locke. Edwards was merely 'postulating a capacity for religious knowledge acceptable to philosophers of his era'.18 To put it simply, where Locke's empiricism said 'you can trust your senses', Edwards counselled 'you can trust your spiritual sense'. According to Bebbington, John Wesley was also decisively influenced by Locke via Peter Browne's The Procedure, Extent, and Limits of Human Understanding (1728). Wesley agreed with the empiricists that knowledge is based on the senses, but where this left the empiricists with at best indirect knowledge of God, Wesley added a sixth sense. 19 This sense operates through faith: 'Faith in the spiritual world is what sight is in the natural'. ${ }^{20}$ Faith is thus as reliable a source of knowledge as sight. Bebbington's precise point here is that the decisively new element in early Evangelicalism was the 'understanding of faith in terms of self-validating sense impressions' ${ }^{21}$ It was thus under philosophical influences that the Revival leaders engaged in what Bebbington terms the 'remoulding of the doctrine of assurance according to empiricist canons'. ${ }^{22}$ Thus the confident activism of Evangelicalism was born from the epistemology of the Enlightenment.

Many accept this dating for the emergence of Evangelicalism. Derek Tidball finds that 'no one is quite sure where the beginning is' (which is hardly true of Bebbington), but despite the difficulty he agrees that 'evangelicalism became a much more easily identified stream within the British church in the eighteenth century'.23 Tidball is also convinced by Bebbington's detailed arguments: 'David Bebbington has persuasively argued that the "evangelical version of Protestantism was created by the Enlightenment". 24 Others appear to accept the conclusion without always commenting on the detail. Writing before Bebbington, Kenneth Hylson-Smith stated circumspectly that Evangelicals could 'trace their history back to the

17 Evangelicalism in Modern Britain, 47-48.

18 Evangelicalism in Modern Britain, 48.

19 Evangelicalism in Modern Britain, 50.

20 Evangelicalism in Modern Britain, 49.

21 'Revival and Enlightenment', 24.

22 Evangelicalism in Modern Britain, 54.

23 Who Are the Evangelicals?, 32.

24 Who Are the Evangelicals?, 36. 
Puritans, the Reformers and the Lollards' and that it was simply in its 'modern phase' that the story began in the Eighteenth Century. ${ }^{25}$ Writing later he quotes Bebbington with approval:

It was in the 1730s that the English-speaking world experienced what has been declared as 'a more important development than any other, before or after, in the history of Protestant Christianity: the emergence of the movement that became Evangelicalism. 26

The dating as well as the definition has crossed the Atlantic; Bebbington himself has co-edited a collection of comparative studies on international evangelicalism from 1700-1900. The introduction to the book sets out the four characteristics and states that 'Evangelical' is the "best word available to describe a fairly discrete network of Protestant Christian movements arising during the eighteenth century in Great Britain and its colonies.' 27

The idea that Evangelicalism was created by the Enlightenment may be questioned in a number of ways. My present aim is a discrete one, to scrutinise the crux of Bebbington's case, his argument that a new Evangelical doctrine of assurance arose from Enlightenment epistemology and grounded a distinctive activism. ${ }^{28}$ I will proceed by testing the claim against the evidence which we-find in selected writings of John Wesley, Jonathan Edwards, and John Newton, and by questioning the type of activism which Bebbington requires to discern the presence of Evangelicalism.

\section{John Wesley on Self-examination}

It is certainly true that Wesley does speak of a direct and immediate assurance normally given on conversion. In Sermon 10 on the witness of the Spirit (1746), he seeks to defend from the extremes of either enthusiasm or scepticism the view that assurance is a gift given to

$25 \mathrm{~K}$. Hylson-Smith, Evangelicals in the Church of England: 1734-1984 (Edinburgh: T \& T Clark, 1988), vii.

26 K. Hylson-Smith, 'Roots of Pan-Evangelicalism: 1735-1835', in For Such a Time as This, ed. S. Brady \& H. Rowdon (London: Scripture Union, 1996), 13747 (137-38), quoting from Evangelicalism in Modern Britain, 20.

27 Evangelicalism: Comparative Studies of Popular Protestantism in North America, the British Isles, and Beyond, 1700-1990, ed. M.A. Noll, D.W. Bebbington, \& G.A. Rawlyk (New York: OUP, 1994), 6.

28 Kenneth J. Stewart has recently asked some important broader questions of Bebbington's account in a paper entitled 'Did Evangelicalism Predate the Eighteenth Century? An Examination of the David Bebbington Thesis'. This is available at http://www.zondervanchurchsource.com/convention/parallel.htm. 
ordinary Christians. In his definition of the witness of the Spirit he argues against identifying it with a rational process of reflection:

The testimony of the Spirit is an inward impression on the soul, whereby the Spirit of God directly 'witnesses to my spirit that I am a child of God'; that Jesus Christ hath loved me, and given himself for me; that all my sins are blotted out, and I, even I, am reconciled to God. ${ }^{29}$

Nonetheless, in the same text Wesley also argues that there is a subsequent conjoined rational testimony from the believer's own spirit. He remarks that the Holy Spirit does not extinguish but perfects reason, citing a number of texts from 1 John which explain the process of rational inference. This shows that while both witnesses are dependent on the work of the Spirit, the second is unlike the first in that it is an indirect witness mediated through rational reflection. Wesley then concludes in syllogistic form: 'It all resolves into this: those who have these marks, they are the children of God. But we have these marks: therefore we are children of God.' 30 Such is the evidence provided for the believer by his conscience reflecting on his conduct.

What is the relation between these two witnesses? In Sermon 11 (1767), Wesley holds that upon conversion the witness of the Spirit exists on its own without the witness of the believer's spirit, there having been no time for the believer to perform evidentiary good works. There is a 'total absence of the fruit of the Spirit' at the time 'when the direct witness is first given'. ${ }^{31}$ As soon as time has passed, however, every believer must ascertain that he is not deluded by the devil, and he must continue to do so. Wesley writes: 'let none ever presume to rest in any supposed testimony of the Spirit which is separate from the fruit of it'.32 Such separation may occur again only under temptation so strong that it clouds the appearance of the fruit to the believer's eye. ${ }^{33}$ Apart from these two cases, both witnesses 'testify conjointly' and are to be heard together since 'while they are joined we cannot be deluded'. ${ }^{34}$

29 The Works of John Wesley, Vol. 1, ed. A.C. Outler (Nashville, TN: Abingdon, 1984), 274.

30 Works, 1:272.

31 Works, 1:294. Sermon 11 contains some differences of emphasis from Sermon 10; on change in Wesley's doctrine of assurance, see K.J. Collins, The Scripture Way of Salvation (Nashville, TN: Abingdon, 1997), 131-52.

32 Works, 1:297.

33 Works, 1:294, 297-98.

34 Works, 1:295. 
In Sermon 10, Wesley goes so far as to specify self-examination as a universal Christian duty: "it highly imports all who desire the salvation of God to consider it with the deepest attention, as they would not deceive their own souls' ${ }^{35}$ Wesley instructs the believer to do this by turning to the witness of his own spirit. Here the selfdeceived will be exposed, since Scripture defines marks 'which a little reflection would convince him, beyond all doubt, were never found in his soul' ${ }^{36} \mathrm{He}$ must have experienced repentance. He must have experienced a dramatic rebirth from death to life; the one who vainly presumes will see that he has not done this. ${ }^{37}$ Or he may look to his present state to find the fruits of the spirit and obedience to the commandments of God; from failing to find them it follows 'with undeniable evidence' for the self-deceiver that 'he has not the true testimony of his own spirit'. ${ }^{38}$ The language which Wesley uses here is unambiguous: this universal Christian duty which proves to the individual that he is not self-deceived is a process of rational reflection on evidence. This witness of the human spirit is not an immediate sense experience.

Wesley can speak eloquently of the witness of the Spirit and he believes that it is discerned by 'spiritual senses' ${ }^{39}$ Indeed, he is concerned to defend such a direct, unmediated sense. But for all his asseverations, Wesley still has to urge the believer to come back to the process of rational enquiry to confirm that he is not self-deceived in his spiritual sense. For example, he pictures a man hearing the voice of God saying 'Thy sins are forgiven thee' ${ }^{40}$ This voice is known by the spiritual sense. Wesley can see the next question coming: 'But how shall I know that my spiritual senses are rightly disposed?' He answers:

Even by the 'testimony of your own spirit'; by 'the answer of a good conscience toward God'. By the fruits which he hath wrought in your spirit you shall know the 'testimony of the Spirit of God'. Hereby you shall know that you are in no delusion; that you have not deceived your own soul. The immediate fruits of the Spirit ruling in the heart are 'love, joy, peace'; 'bowels of mercies, humbleness of mind, meekness, gentleness, longsuffering'. And the outward fruits are the doing good to all men, the doing no evil to any, and the walking in the light-a zealous, uniform obedience to all the commandments of God. ${ }^{41}$

\footnotetext{
35 Works, 1:277.

36 Works, 1:278.

37 Works, 1:278-79.

38 Works, 1:281.

39 Works, $1: 282$

40 Works, $1: 282$.

41 Works, 1:283.
} 
This test which all believers must apply to themselves to check that they are rightly perceiving the witness of the Spirit is the rational scrutiny of their own works.

In sum, for all but the newest believer or the believer under the strongest temptation, Wesley urges self-examination and the confirmation of the witness of the Spirit by syllogistic reasoning applied to the evidence of an attentive conscience. He looks to correct not only those who denied the witness of the Spirit, but also those who 'have mistaken the voice of their own imagination for this "witness of the Spirit" of God, and thence idly presumed they were the children of God while they were doing the works of the devil!'.42 Nor is this a once-off check for the fruit of the Spirit, since both witnesses operate conjointly. The believer must, normatively and persistently, look for the fruit of the spirit.

The resulting Wesleyan appeal to self-examination is a real problem for the thesis that Wesley's care-free doctrine of assurance is the explanation of Evangelical activism. The Christian could only be free from self-scrutiny at the very outset of the Christian life or in the worst of times, as Wesley himself knew in his own experience. Such brief times without scrutiny will not suffice to explain the activism of Evangelicals. This is not to deny that assurance was more widely experienced by Wesleyans, but it is to counter Bebbington's argument that the Methodists were freed for their activism by leaving the selfexamination of the Puritans behind them.

\section{John Wesley on Spiritual Sense}

From Bebbington's account we would expect to find Wesley casting spiritual sense in terms of physical sense. In this piece he does something more subtle. When he speaks of the witness of the believer's own spirit, Wesley readily draws such comparisons. Hence he says that the believer has an 'immediate consciousness' that he obeys God in the same way as he has an immediate consciousness that he is alive or is at ease and not in pain. ${ }^{43}$ Such consciousness entails the believer's reflection on himself, a conception amenable to Locke. The comparison here is one of manner; both are alike rational processes of reflection. But Wesley then accents not the similarity but the contrast with the witness of the Spirit of God:

42 Works, 1:269.

43 Works, 1:273. 
The manner how the divine testimony is manifested to the heart I do not take upon me to explain. 'Such knowledge is too wonderful and excellent for me; I cannot attain unto it.' 'The wind bloweth; and I hear the sound thereof'; but I cannot 'tell how it cometh, or whither it goeth'. As no one knoweth the things of a man save the spirit of the man that is in him, so the manner of the things of God knoweth no one save the Spirit of God. 44

With this witness Wesley will indeed allow a simple comparison with sense experience in saying that the testimony of the Spirit is no more doubtful than the shining of the sun. But the comparison here is a comparison pertaining to the degree of certainty, not to the manner of certainty. The manner of the two witnesses is beyond comparison since one relies on human reflection and the other on the direct work of the unfathomable Spirit of God. This means that Wesley is careful to avoid the epistemic step from Enlightenment views of knowledge based on the senses to the doctrine of assurance. The spiritual sense is radically different from the other senses. That, of course, is why many Enlightenment thinkers rejected it.

Moreover, writers on Wesley frequently point out that he found his idea of spiritual sense in diverse sources, most of them pre-dating the Enlightenment. As Theodore Runyon notes, 'there is a long tradition in the Scriptures and in Christian history which speaks of spiritual senses' ${ }^{45}$ The following text which Runyon cites from the patristic Macarian Homilies provides an excellent example of the antiquity of the tradition:

Our Lord Jesus Christ came for this very reason, that he might change, and renew, and create afresh this soul that had been perverted by vile affections, tempering it with his own Divine Spirit. He came to work a new mind, a new soul, and new eyes, new ears, a new spiritual tongue $[\ldots] .46$

Here, long before the Enlightenment and in a text read by Wesley, we find the doctrine of spiritual senses created anew in the believer. If this much of the doctrine was available to Wesley in the pre-Enlightenment texts which he was reading, it is a serious overstatement to say that the Wesleyan doctrine of assurance was in fact created by the Enlightenment. We cannot even posit a rediscovery of the idea of spiritual sense in the 1730 s since, as Randy Maddox notes, it had survived in Puritan writers. ${ }^{47}$ To take one example, John Owen in his

44 Works, 1:276.

45 T. Runyon, The New Creation: John Wesley's Theology Today (Nashville, TN: Abingdon, 1998), 74.

46 The New Creation, 75

47 R.L. Maddox, Responsible Grace: John Wesley's Practical Theology (Nashville, TN: Abingdon, 1994), 27-28 cites as possible sources for the idea of 
Pneumatologia can speak of a unique 'spiritual sense of the defilement of sin' and a 'gracious view' of the cleansing power of the blood of Christ which is worked in the believer by the Holy Spirit and is impossible in a natural man. ${ }^{48}$ Even the idea of a self-validating knowledge of God through faith in his Word remained an unbroken tenet of Reformed theology from the Sixteenth Century. Calvin gave memorable expression to it in the Institutes I. vii, and he was closely followed by the Puritans. Owen in The Reason of Faith (Book VI of Pneumatologia) uses the language of the senses to describe the way in which the Scripture 'evinceth this its divine efficacy by that spiritual saving light which it conveys into and imparts on the minds of believers'. Through Scripture the Holy Spirit gives a self-validating knowledge to believers:

God by his Holy Spirit doth secretly and effectually persuade and satisfy the minds and souls of believers in the divine truth and authority of the Scriptures, whereby he infallibly secures their faith against all objections and temptations whatsoever [...]. ${ }^{49}$

I do not for a moment want to deny that Wesley shaped his idea of spiritual sense in the language of, and relevantly to, his times. The leitmotif of Bebbington's work is the claim that Evangelicalism has always been fashioned by its contexts. In principle that is an unobjectionable claim, but it is quite another step to say that Evangelicalism was 'created by' one of its contexts. A shared vocabulary is not sufficient to demonstrate an intellectual origin, especially when there are obvious alternatives available to account for the provenance of the substance of Wesley's ideas. We will return to this point in consideration of Edwards.

\section{Jonathan Edwards on Spiritual Sense}

From his early works onward Edwards, like Wesley, held to a high view of the new sense given to the believer by the Holy Spirit. His sermon A Divine and Supernatural Light, which was delivered in 1733 and published the following year, argues from Matthew 16:17 for the necessity of a Spirit-given revelation of God. This is not the

spiritual sense John Norris, the Macarian Homilies, Western spiritual, Pietist and Puritan writers.

48 The Works of John Owen, ed. W.H. Goold (Edinburgh: Banner of Truth, 1965, repr. 1994), 3:443.

49 Works of John Owen, 4:99-100. 
same as a moral conviction of sin, an impression on the imagination, a merely speculative knowledge or an instance of being affected by the things of religion. Rather, it is a direct, unmediated sense of divine excellency which affects the 'heart', the term which Edwards uses for the entire 'cognitive-volitional-affective complex' of the human person. 50 As Edwards puts it, 'The evidence that they that are spiritually enlightened have of the truth of the things of religion, is a kind of intuitive and immediate evidence'. Such evidence might suggest that Edwards did indeed preach and write about an immediate, early assurance for Christians. That conclusion, however, can only be reached if we do not pause to investigate the content of the assurance which is thus given to the believer. Divine and Supernatural Light is a sermon concerned exclusively with the objective truth of the Gospel, and not with the truth of the claim that any individual is saved. In other words, Edwards advocates a direct, immediate assurance that there is such an excellent being as the Gospel proclaims. He does not advocate an immediate sense in the Christian that he or she is saved. This is a traditional distinction within Reformed theology, and it is no surprise to find that when Edwards comes to explain how any individual can find assurance of salvation the answer is quite different, as we will see below. For now the point is that when in such texts Edwards speaks of an immediate certainty, he is not speaking about the certainty of salvation that fuels confident action.

Having granted that there is a real emphasis on immediate spiritual sense in Edwards, it is also necessary to consider the provenance of this emphasis. The 1746 Treatise Concerning Religious Affections is often said to be his most revealingly Lockean text at this point. In it, Edwards delineates the marks of religious affections which accompany a saving work of the Spirit. When he discusses the first of his twelve signs of genuine affections, he again defends the concept of a new spiritual sense against its detractors:

in those gracious exercises and affections which are wrought in the minds of the saints, through the saving influences of the Spirit of God, there is a new inward perception or sensation of their minds, entirely different in its nature

50 This helpful definition of the heart in Edwards is given by Brad Walton in Jonathan Edwards, Religious Affections and the Puritan Analysis of True Piety, Spiritual Sensation and Heart Religion (Lewiston, NY: Edwin Mellen, 2002), e.g. 209. For the arguments from $A$ Divine and Supernatural Light, see The Works of Jonathan Edwards, Vol. 17 ed. M. Valeri (New Haven: Yale UP, 1999), $410 \mathrm{ff}$. 
and kind, from anything that ever their minds were the subjects of before they were sanctified. ${ }^{51}$

Edwards is happy to cast this spiritual sense in language favourable to philosophers: he acknowledges that it is 'what some metaphysicians call a new simple idea'. 52 The exact relation between Edwards and such metaphysicians is, however, a matter of great and lively contention. Perry Miller emphasised the Lockean identity of Edwards. Norman Fiering countered by emphasising his debt to Nicolas Malebranche, and writing of Miller's work as 'rhetorically brilliant but utterly misleading in content $[\ldots]$ an unaccountable lapse in the scholarship of one of the greatest of American historians'.53 Conrad Cherry identified Edwards as 'first and last a Puritan theologian' rather than an Enlightenment thinker. ${ }^{54}$ The disagreement over Edwards as philosopher or Puritan has raged on in the literature, and it is beyond the scope of this article to deal with it thoroughly. 55 Nonetheless, it is vital to Bebbington's reading of Evangelical origins that Edwards was decisively influenced by Locke, a claim which is at the centre of this controversy. Some kind of assessment is thus unavoidable. In short, I find that there are two insuperable problems with the attempt to class Edwards as in any significant way a Lockean. First, he disagrees with Locke on a number of philosophical issues central to both their intellectual projects. Secondly, as with Wesley, recent work has shown conclusively that the language. and even the key concepts used by Edwards are explicable in terms of his Augustinian-Reformed theological heritage without appeal to Locke except at a few isolated and insubstantial points, and for apologetic purposes.

First, we turn to the disagreements with Locke. Many examples of clear divergence between Edwards and Locke could be cited, but two brief and pointed instances will suffice to show the extent of the problem. With Locke, Edwards speaks of simple ideas generated by perceiving a particular content and reflecting on that content with reason. And yet, going far beyond and against Locke, he understands

51 The Works of Jonathan Edwards, Vol. 2 ed. J.E. Smith (New Haven: Yale UP, 1959), 205.

52 Works of Jonathan Edwards, 2:205.

53 For Miller see especially 'Jonathan Edwards on the Sense of the Heart', HTR, 41 (1948), 123-45, and Jonathan Edwards (New York: William Sloane, 1949). The Fiering quotation is from Jonathan Edwards's Moral Thought and Its British Context (Chapel Hill: University of North Carolina, 1981), 373.

54 Conrad Cherry, The Theology of Jonathan Edwards: A Reappraisal (Bloomington and Indianapolis: Indiana UP, 1966, repr. 1990), xxiii.

55 For a survey of the debate in relation to the Religious Affections, see Walton, Jonathan Edwards, c. 1. 
the content of spiritual perception to be divine excellency and holds that it can only be perceived through the illuminating work of the Holy Spirit in the individual creating a new sense. This particular supernatural claim would have been entirely unacceptable to the philosopher. Consequently, even here, where Edwards is using language definitely attributable to Locke, he is giving it a quite contradictory meaning. As Brad Walton comments in his recent work, 'On the rare occasion he uses a Lockean technical term, such as "simple idea," he does so metaphorically, in a un-Lockean sense, for the purposes of illustration by analogy.' ${ }^{56}$ Secondly, the whole aim of the Religious Affections can be understood as a rejection of Lockean style hostility to religious enthusiasm. Edwards sets out to establish the centrality of affections in perception and thus disagrees with Locke and his own contemporaries such as Charles Chauncy in arguing that the Christian individual is strongly inclined to the divine excellency which is spiritually perceived. These and many other examples show that, as Walton puts it, Edwards has 'a panoply of unLockean concepts' which are deployed at crucial points in the Affections. 57

Secondly, there is the sufficiency of the Augustinian-Reformed theological heritage as an explanation for the language and concepts used by Edwards. Edwards himself would have been troubled to think that his ideas were novel and based on a recent philosophical development. It is no surprise that he takes us to the Scriptures to show the origin of his concept of spiritual sense:

Hence the work of the Spirit of God in regeneration is often in Scripture compared to the giving a new sense, giving eyes to see, and ears to hear, unstopping the ears of the deaf, and opening the eyes of them that were born blind, and turning from darkness unto light. 58

In terms of his more immediate background, Edwards repeatedly cites long passages from Puritan writers in his footnotes. These passages and others from texts which Edwards had read contain the concepts which Edwards is meant to have acquired from his adherence to Locke. For example, Edwards cites the following passage from John Owen on spiritual perception:

The true nature of saving illumination consists in this, that it give the mind such a direct intuitive insight and prospect into spiritual things, as that in

56 Jonathan Edwards, 218.

57 Jonathan Edwards, 216.

58 Works, 2:206. 
their own spiritual nature they suit, please, and satisfy it; so that it is transformed into them, cast into the mould of them, and rests in them. .59

Edwards is here defending his second authentic sign, and he uses this text from Owen's Pneumatologia to expand on his own point that in a saving work of the Spirit the true saint delights affectively in the spiritual sense of who God is.

At this point it is important to note the recent work of Walton on the Religious Affections. 60 Walton has done something which, in the light of the footnotes in the Affections, ought to have been a very obvious move to make long ago to advance the scholarly deadlock over Edwards. That is, he has worked his way through a long list of Puritan writers to search for the kind of religious psychology which we find in Edwards. And he has found it abundantly. He carefully traces the pre-history of the Edwardsean conceptions of, inter alia, assurance, illumination, spiritual sense, the affections, authentic signs, and the heart. His focus is on writers of the Seventeenth Century, but he goes back through the Mediaeval period to the Scriptures and classical philosophy. I do not have the space to detail his findings, but it is hard to see how his work will not prove to be an insurmountable challenge to anyone who wishes to cling to Miller's understanding of Edwards, or to any view which sees the well-spring of Edwardsean theology in the Enlightenment. I cite just two of Walton's more apposite Puritan examples to supplement my own reference to Owen. First is Thomas Goodwin (1600-1680) sounding just like Edwards on a new sense: "whenas God regenerateth any man, and constitutes him a new creature, lo, that man hath a new eye to see, an ear to hear, and all sorts of new senses to take in all sorts of spiritual things'. ${ }^{61}$ Just as sensual in his language is John Flavel (1630-91) commenting that among true believers, 'you will find also tasting as well as enlightening: so that they seem to abound not only in knowledge, but in sense also; i.e., in some kind of experience of what they know: for experience is the bringing of things to the test of the spiritual sense.' 62 With page upon page of such evidence carefully detailed and expounded, Walton has further undermined any conception of an Edwards decisively shaped by Locke. But he has also raised serious questions about any attempts to make other Enlightenment thinkers decisive for the shape of Edwards's thought.

59 Works, 2:250; see Owen, Works, 3:238.

60 See n. 50 above.

61 Jonathan Edwards, 85.

62 Jonathan Edwards, 120. 
Perhaps the most accurate assessment of the Enlightenment influence on Edwards is that he was engaged in an apologetic project in which he used the language and concepts of his opponents to his own theological ends. There are pointers in this direction in various commentators. Fiering, who is eager to make the case for Malebranche as an important influence, agrees that Edwards aimed 'to give seventeenth-century Puritan pietism a respectable philosophical structure, which would make it rationally credible and more enduring than it could be without the aid of philosophy'. ${ }^{63}$ Michael McClymond pursues a similar line of argument in his recent work, arguing that Edwards used contemporary conceptions for an apologetic purpose. 64 Having commented on Walton's work, it is only fair to point out that he himself would probably eschew even this concession to the claim of Enlightenment influence, since he avers that nearly all of the terminology used by Edwards in his discussion of conversion is wholly traditional. ${ }^{65}$ Fortunately, we do not have to adjudicate here on the precise extent of the terminological influence of the Enlightenment. It is enough to note that at the least Walton has shown that the substance of Edwards's thought is not derived from the Enlightenment, while at the most he has shown that even its language was derived from elsewhere. Either way, following earlier work against the Lockean hypothesis, his research undermines the conception of Edwards on which Bebbington's assessment of the origins of Evangelicalism depends.

\section{Edwards on Imagination and Assurance}

When in the Religious Affections Edwards considers how an individual can discern saving spiritual affections, he again employs the concept of spiritual sense. Here he is concerned to show how true sense and affection can be distinguished from false. It is this discussion of subjective self-knowledge which is germane to the doctrine of assurance, rather than his other work on the knowledge of the objective truth of the Gospel. Edwards gives an account of assurance which is quite distinct from that held by Wesley, with the result that the two men taught strongly opposed doctrines. This

63 Jonathan Edwards's Moral Thought, 60.

64 Michael J. McClymond, Encounters with God: An Approach to the Theology of Jonathan Edwards (New York: OUP, 1998), 7, 115 n. 17.

65 Jonathan Edwards, 218. 
disagreement undermines the idea that there was a coherent new doctrine at the heart of nascent Evangelicalism.

Specifically, Edwards refuses to count as evidence for authentic spiritual sense and affection any phenomenon which pertains to the imagination, which he defines as:

that power of the mind, whereby it can have a conception, or idea of things of an external or outward nature (that is, of such sort of things as are the objects of the outward senses), when those things are not present, and be not perceived by the senses. ${ }^{66}$

This definition leads him to reject the same phenomena attesting the direct witness by the Spirit which Wesley endorses (and which were relied on by many in New England). As we saw above, Wesley favourably cites the example of a man hearing the statement 'Thy sins are forgiven thee'. ${ }^{67}$ Edwards cites this as just the kind of thing which someone deluded by Satan might use as the basis for his assurance. 68 It is not just that this may be either a good or bad basis for assurance (which Wesley himself seems prepared to admit); it is that such a supposedly direct witness can never be any ground for a Christian's assurance. Edwards holds that anything which could be emulated by the devil is automatically excluded as a ground of assurance. It may not necessarily be a satanic witness; it may even be a work of the Spirit, but if it is a work of the Spirit it is not a witness to the salvation of the individual concerned:

So if the Spirit of God impresses on a man's imagination, either in a dream, or when he is awake, any outward ideas of any of the senses, either voices, or shapes and colors, 'tis only exciting ideas of the same kind that he has by natural principles and senses. 69

The difference can be set out with an example which Bebbington himself uses when he asserts the novelty of the Evangelical epistemology. In the middle of an account which makes no distinction between Edwards and Wesley, Bebbington tells us that the rank and file 'formulated their experience in the same way' as their leaders. He provides this example:

'By the eye of faith,' wrote an early Methodist about his sense of pardon through the work of Christ, 'I had as real a view of His agony on Calvary as

66 Works, 2:210-11.

67 Wesley, Works, 1:282.

68 Edwards, Works, 2:149.

69 Works, 2:207. 
ever I had of any object by the eye of sense.' The understanding of faith in terms of self-validating sense impressions was a striking novelty. ${ }^{70}$

Edwards refers to just such an instance:

Some have had ideas of Christ's hanging on the cross, and his blood running from his wounds; and this they call a spiritual sight of Christ crucified, and the way of salvation by his blood. [...] These things they have called having the inward call of Christ, hearing the voice of Christ spiritually in their hearts, having the witness of the Spirit, and the inward testimony of the love of Christ, etc. ${ }^{71}$

Does Edwards affirm such a witness? On the contrary, he speaks of it in strongly disparaging terms. The idea that the man has of Christ 'is no better in itself, than the external idea that the Jews his enemies had, who stood round his cross and saw this with their bodily eyes'. ${ }^{72}$ Any kind of man can have such images: "A natural man is capable of having an idea, and a lively idea of shapes and colors and sounds when they are absent, and as capable as a regenerate man is: so there is nothing supernatural in them' ${ }^{73}$ Edwards is prepared to use strong language of this experience: 'There appears to be nothing in their nature above the power of the devil' ${ }^{74}$ Indeed, 'it is certain also that the devil can excite, and often hath excited such ideas'. ${ }^{75}$ Edwards has by this point already used language of an even stronger nature, describing the way in which such visions denigrate Jesus Christ. They make the spiritual sense no better than the senses which even the beasts of the field have, 'as it were, a turning Christ, or the divine nature in the soul, into a mere animal'. 76

Behind this rejection of such experiences lies Edwards's hostility to imagination as the source of religious knowledge. He repeatedly attacks any source of assurance which could have been produced by the imagination, including ideas of shapes, words spoken, and bodily sensations. For Edwards, imagination is the prime instrument which Satan uses in deceiving people about their spiritual status. It is frequently a source of false knowledge, contrasted with the true enlightenment which is the fourth sign of gracious affections. Edwards explains that the devil has no access to the thoughts in an individual's mind, unlike God to whom such knowledge is reserved.

70 'Revival and Enlightenment', 23-24.

71 Works, 2:211-12.

72 Works, 2:214.

73 Works, 2:213.

74 Works, 2:215.

75 Works, 2:216.

76 Works, 2:213. 
Hence 'it must be only by the imagination, that Satan has access to the soul, to tempt and delude it, or suggest anything to it'. ${ }^{77}$ Persons who do not keep a close guard will be highly susceptible to the devil when he masquerades as an angel of light with 'inward whispers, and immediate suggestions of facts and events, pleasant voices, beautiful images, and other impressions on the imagination' ${ }^{78}$ True affections may produce lively imaginations, but lively imaginations are no assurance of true affections. Under the discussion of the fifth authentic sign, Edwards again describes imaginings as one of the types of false conviction:

The extraordinary impressions which are made on the imaginations of some persons, in the visions, and immediate strong impulses and suggestions that they have, as though they saw sights, and had words spoken to 'em, may, and often do beget a strong persuasion of the truth of invisible things. ${ }^{79}$

\section{Edwards on Perseverance in Good Works as the Witness of the Spirit}

The feeling one gets when reading the Religious Affections as a Christian is a feeling of gradual, painful deconstruction. Piece by piece Edwards removes the spiritual props which so many rely on. We take a sharp intake of breath as yet another part of the evidence which we have trusted in to show the genuineness of our profession is dismantled. By this stage in the work a whole host of supposed witnesses have been removed. The reader is beginning to wonder exactly what sound basis for assurance will be left to Edwards. He is aware of this dynamic, indeed it is deliberate and accounts for much of the spiritual power of the work. Just after his dismissal of images, voices, and even the spontaneous recollection of Scriptural texts, he anticipates the reader's growing concern: 'But here, some may be ready to say, what, is there no such thing as any particular spiritual application of the promises of Scripture by the Spirit of God?' ${ }^{80}$ His reply unmistakably affirms such an application, but in a way that contradicts what will be Wesley's doctrine of assurance and Bebbington's picture of Edwards himself. The application of the promises is to be found in the fruit of the Spirit: 'A spiritual application

77 Works, 2:289.

78 Works, 2:290.

79 Works, 2:309.

80 Works, 2:224. 
of the Word of God consists in applying it to the heart, in spiritually enlightening, sanctifying influences.' The application of the offer of the Gospel entails a sequence of stages. It means giving a spiritual sense of the blessings offered, of the grace of the offerer, of his excellency, faithfulness, and sufficiency for it, eliciting a response, and 'thus giving the man evidence of his title to the thing offered.' 81

We must consider carefully the use of the term 'evidence' here under the account of the first authentic sign. Where Wesley posits a direct, unmediated witness, Edwards routes all assurance via evidence considered by the individual's conscience, in these cases the sanctifying influences of the Spirit and an obedient response to the Gospel. Edwards is adamant that because there is no statement in the Scriptures about any individual Christian believer being saved, no one can have a direct communication that they themselves are forgiven: 'there are no propositions to be found in the Bible declaring that such and such particular persons, independent on any previous knowledge of any qualifications, are forgiven and beloved of God'. Anyone who is comforted by such a statement is actually comforted 'by another word, a word newly coined, and not any Word of God contained in the Bible. And thus many persons are vainly affected and deluded.' 82 Edwards finds that people have been misled by the term 'witness' into denying that the Spirit uses evidence. They have done this by failing to note how the words 'witness' and 'testimony' are used in the New Testament. There, he points out (using Heb. 2:4 as an example), 'such terms often signify, not only a mere declaring and asserting a thing to be true, but holding forth evidence from whence a thing may be argued and proved to be true. 83

Edwards explicates his own conception of the witness of the Spirit by using what he deems to be the biblical equivalents 'seal' ( $\sigma \phi \rho \alpha \gamma i \varsigma)$ and 'earnest' ( $\alpha \rho \rho \alpha \beta \omega \dot{v})$. Both point to the role of fruit as evidence in the Spirit's witness. The seal denotes 'not an immediate voice or suggestion, but some work or effect of the Spirit, that is left as a divine mark upon the soul, to be an evidence, by which God's children might be known. '84 This mark assures by 'exhibiting clear evidence to the conscience'. The seal, which Edwards compares to a royal signet, is thus 'enstamped in so fair and clear a manner, as to be plain to the 
eye of conscience'. ${ }^{85}$ The earnest of the Spirit means the same thing. ${ }^{86}$ In sum, the seal is understood by Edwards as the 'sanctifying communication and influence of the Spirit' ${ }^{87}$ Edwards draws these comments together by turning to Rom. 8:16. Discussing Paul's description of the Spirit as the 'Spirit of adoption', he explains that the Spirit works in 'disposing us to behave towards God as to a Father' ${ }^{88}$ The troubled Christian must therefore turn his conscience to look for evidence of childlike obedience to the Father if he wants assurance that his affections are genuine. Against the position later taken by Wesley, Edwards argues that he should not expect a twofold witness: 'When the apostle Paul speaks of the Spirit of God bearing witness with our spirit, he is not to be understood of two spirits, that are two separate, collateral, independent witnesses [... $]^{8}{ }^{89}$

The position which Edwards takes on evidence emerges most clearly in the treatment of the twelfth authentic sign, defined by the claim that 'gracious and holy affections have their exercise and fruit in Christian practice' .90 The treatment of this sign occupies the greater part of Part Three of the Affections, and Edwards explains that the other eleven aspects of gracious affections show why they will always culminate in Christian practice. In terms of the structure of the book and the direction of the argument, this sign is the centrepiece. Edwards takes great care in explaining it. $\mathrm{He}$ argues that Christian practice has three features. It entails a universal conformity to Christian rules (by which he means a full range of obedience, not perfect obedience). It take priority over all other things in an individual's life, and it persists through trials and testing until the end. This last point is very important, since Edwards holds that it is in trials that the true nature of an individual's affections is revealed: perseverance is defined as 'the continuance of professors in the practice of their duty, and being steadfast in an holy walk, through the various trials that they meet with'. ${ }^{91}$

Having explained what he means by 'Christian practice', Edwards distinguishes two aspects of its evidentiary function. On the one hand, it serves as a sign by which others can discern the authenticity of a

85 Works, 2:233.

86 Works, 2:234ff.

87 Works, 2:237.

88 Works, 2:237.

89 Works, 2:239.

90 Works, 2:383.

91 Works, 2:389. 
professor's affections. In so doing they will consider only the external good works which an individual does, since they have no direct access to his inner life. Despite the fact that their conclusions will thus never attain infallibility, 'practice is the best evidence of the sincerity of professing Christians'. ${ }^{92}$ On the other hand, an individual's own conscience can perceive his inner life as well as his outward actions. This means that the individual's self-scrutiny involves the consideration of a whole range of evidence which is not available to others, namely the acts of the soul. Edwards explains that practice is the culmination of a process which begins in the soul; therefore the entire activity of the soul which precedes the action of the body must be considered: 'the whole exercise of the spirit of the mind, in the action, must be taken in, with the end acted for, and the respect the soul then has to God, etc.'. ${ }^{93}$ Here we glimpse a sight of the vista which unfolds in The Freedom of the Will: Edwards is clear that any genuinely free external act of the body will be united to an internal act of the will which will be available to the conscience for scrutiny. 94 Just as Christian practice is the best evidence for another to discern genuine affections, so for the individual: it is 'the chief of all the evidences of a saving sincerity in religion, to the consciences of the professors of it' ${ }^{95}$ Edwards reaches a crescendo of praise for Christian practice:

Now from all that has been said, I think it to be abundantly manifest, that Christian practice is the most proper evidence of the gracious sincerity of professors, to themselves and others; and the chief of all the marks of grace, the sign of signs, and evidence of evidences, that which seals and crowns all other signs. 96

At the end of Religious Affections, Edwards anticipates the objection that his position negates the role of Christian experience. In reply he makes a move which further highlights how different his view is from that of Wesley. Where Wesley speaks of a directly communicated spiritual sense, Edwards subsumes spiritual sense itself within his account of assurance based on good works. He defends his position by showing that his account makes much of experience when experience is rightly understood as including holy practice; indeed, 'nothing is so properly called by the name of experimental religion'.${ }^{97}$ In particular,

\footnotetext{
Works, 2:409.

Works, 2:423.

Works, 2:425-26.

Works, 2:426.

Works, 2:443.

Works, 2:452.
} 
he affirms the evidentiary role of the experience of endurance in the midst of trials:

To have at such a time that sense of divine things, that apprehension of the truth, importance and excellency of the things of religion, which then sways and prevails, and governs his heart and hands; this is the most excellent spiritual light, and these are the most distinguishing discoveries. ${ }^{98}$

This statement reflects the earlier point that Edwards sees a continuity between inner and outer actions, actions of the soul and the body. The true 'spiritual light' here works through from the grasp of divine things all the way to the bodily deeds done by the hands.

At one point Edwards turns to address the question of instant assurance, aware that his view might be taken to exclude even its possibility. In a statement the tone of which hardly suggests a new, bold Evangelicalism, he allows that early assurance can be experienced: 'Tis possible that a man may have a good assurance of a state of grace, at his first conversion, before he has had opportunity to gain assurance, by this great evidence I am speaking of.' 99 This experience is compared to a man setting off on a journey to claim a promised treasure; the man can know that he is determined to arrive as soon as the offer is first made. But quickly Edwards moves on to assert that this 'don't hinder but that his actual going for it is the highest and most proper evidence of his being willing'. 100

In the light of such arguments it is no surprise that in the course of the work Edwards urges a thorough, suspicious and relentless selfexamination, most notably on the issue of pride and humility. His advice needs to be cited at length to show just how committed to radically searching self-examination he was:

Let not the reader lightly pass over these things in application to himself. If you once have taken it in, that it is a bad sign for a person to be apt to think himself a better saint than others, there will arise a blinding prejudice in your own favor; and there will probably be need of a great strictness of selfexamination, in order to determine whether it be so with you. If on the proposal of the question, you answer, 'No, it seems to me, none are so bad as I.' Don't let the matter pass off so; but examine again, whether or no you don't think yourself better than others on this very account, because you imagine you think so meanly of yourself. Haven't you a high opinion of this humility? And if you answer again, 'No; I have not a high opinion of my humility; it seems to me I am as proud as the devil'; yet examine again, whether self-conceit don't rise up under this cover; whether on this very

98 Works, 2:453.

99 Works, 2:443.

100 Works, 2:443. 
account, that you think yourself as proud as the devil, you don't think yourself to be very humble. 101

This sounds far more like the voice of the Puritan of Puritans than of a carefree Evangelical ready for action.

In the Religious Affections we therefore find a doctrine of assurance based not on Enlightenment epistemology but on a close attention to the language of Scripture. We find a doctrine concerned to urge not reliance on a direct witness, but careful scrutiny of on-going good works done in a filial disposition amid trials and temptations. It is notable that it was after writing this treatise, perhaps a more cautious treatment than his earlier revival writings, that Edwards himself worked among the Indians in the frontier town of Stockbridge. Where we would expect from Bebbington to find the earlier, possibly more confident theology fuelling evangelistic activism, we find that Edwards's activism followed his attack on the idea of a direct witness. Perhaps the opposite of Bebbington's view is the case; that a more reserved view of assurance encourages activism in an attempt to provide the evidence which comforts the conscience. Interestingly, this is suggested by the experience of Wesley as well as Edwards. The personal history of Wesley at this point is the mirror image of Edwards. While for Edwards activism followed a less easy doctrine of assurance, for Wesley it preceded it, since it was prior to his experience of assurance that Wesley engaged in his endeavours in the Holy Club in Oxford and made his missionary trip to Georgia.

If we have not already seen enough to demonstrate that there was not a new carefree view of early assurance, let alone a consensus on the subject, we will attend briefly to the treatment which the Religious Affections received at the hands of John Wesley. Wesley produced abridged editions of many works as part of his Christian Library, one of which was the Affections. Only a sixth of the work survived his editorial knife, with the twelve signs of Part 3 being reduced to eight. While many of Wesley's excisions in other works were purely for brevity and ease of reading, this was nothing short of a consistent theological programme, designed to purge the work of its errors. In introducing the work, Wesley himself admitted that this was his strategy. It is plain that he did not like the treatise as he found it because he thought that it was a defence of the doctrine of the final perseverance of all believers. Edwards, he judged, wrote in order to explain why, since the Revival, so many 'believers' seemed to have

101 Works, 2:336. 
fallen away. Wesley judges that Edwards goes to great lengths to reach his goal:

He heaps together so many curious, subtile, metaphysical distinctions, as are sufficient to puzzle the brain, and confound the intellects, of all the plain men and women in the universe; and to make them doubt of, if not wholly deny, all the work which God had wrought in their souls.

In all, Wesley found the treatise a 'dangerous heap, wherein much wholesome food is mixed with much deadly poison'. ${ }^{102}$ As we would expect from what we have seen of their respective positions, Wesley was quite happy to maintain Edwards's defence of works as authenticating signs, but he cut the strongest material which explained supposed examples of the direct witness as the fruit of delusory imagination. Gone is the attack on the idea of an immediate direct witness alongside Christian practice which we find when Edwards describes the first sign of authentic affections. Wesley's opening fulmination and his strategic omission confirm that there was no uniform early Evangelical doctrine of assurance, while his inclusion of Edwards's material on the centrality of works shows that there was no uniform rejection of the Puritan emphasis on self-examination.

\section{John Newton on Assurance}

The lack of early Evangelical uniformity on assurance is further highlighted by the teaching of John Newton. Bebbington cites Newton as an example of an evangelical who departed from traditional Puritan theological distinctions. These, Bebbington quotes Newton saying, were 'not Scriptural modes of expression, nor do they appear to me to throw light upon the subject'. ${ }^{103}$ Newton functions for Bebbington as an example of Evangelical dependence on the Enlightenment in that he favoured the empirical method rather than Puritan systematization in his theological reasoning. For our purposes, Newton is of interest not because of his method, but because of his doctrine of assurance as it is found in his sermon ' $O f$ the Assurance of Faith'.

Like Wesley, Newton speaks of assurance as a common privilege of Christians, though in context he may mean simply to assert that

102 The Work of the Holy Spirit in the Human Heart, by The Rev. Jonathan Edwards M.A. [...] Being Two Tracts on that Subject Abridged by Rev. John Wesley, A.M., ed. T.O. Summers (Salem, Ohio: Schmul Publishing, 1998), 49.

103 'Revival and Enlightenment', 24, quoting from The Works of the Rev. John Newton, (London: 1808), 2:587. 
assurance is not exclusively apostolic, an observation he makes since he is discussing an apostolic text, 1 John 5:19.104 But Newton's view of who has had assurance in the history of the church is distinctly reserved. Even in the apostolic period it was only 'some' who could say they were children of God, 'some' who had such assurance. 105 In the later history of the church there have been 'many' who could echo the apostle's words, and in his own day he trusts that 'there are more than a few' in such a position, though there are hindrances 'which keep so many who are interested in the Gospel salvation from enjoying their privilege' ${ }^{106}$ Indeed, he finds that the 'the greater part [...] live far below their just right and privilege'. ${ }^{107}$

The reason for Newton's hesitation becomes clear when he discusses the stage at which assurance is given and the ground on which it is established. The young believer is unlikely to have much hope in God's mercy, since hope depends on the knowledge of Christ which in turn 'in a measure depends on our knowledge of the Scriptures, which testify of him, and on the proofs we have had of his wisdom, grace, and love to ourselves'. The young convert lacks these. Hence, Newton says, with a significant choice of words, 'though his eyes are opened, his sight is not yet confirmed, nor his spiritual senses exercised'. ${ }^{108}$ The new believer has underdeveloped spiritual senses which are not yet functioning to give him assurance. He is also tempted to legalism, which further weakens assurance. To make his point, Newton quotes Paul's persuasion that he will be rewarded (2 Tim. 1:12), a persuasion which he notes is expressed at the end of his life.

Newton's definition of the ground of assurance is also interestingly distinct from Wesley's account of the two witnesses:

Assurance is the result of a competent spiritual knowledge of the person and work of Christ as revealed in the Gospel, and a consciousness of dependence on him and his work alone for salvation. ${ }^{109}$

This process of knowledge and dependence is expressly distinguished from three false grounds; from an 'instantaneous impression of the Spirit of God upon the mind, independent of his word', from the

104 Works of the Rev. John Newton, 6 Vols, (3rd edn; London: Hamilton, Adams, 1824), 2:585.

105 Works of the Rev. John Newton, 2:585.

106 Works of the Rev. John Newton, 2:585, 586.

107 Works of the Rev. John Newton, 2:586.

108 Works of the Rev. John Newton, 2:589.

109 Works of the Rev. John Newton, 2:593. 
'powerful application of a particular text of Scripture', and from the consideration of 'inherent sanctification, or a considerable increase of it'. In other words, it is distinct from Wesley's immediate direct and indirect witness, as well as from Edwards' indirect witness. Nonetheless, at the end of his sermon, even Newton cannot avoid some appeal to works as negative evidence, warning that 'if your love and dependence are not fixed on the Lord Jesus Christ, if your tempers and practice are not governed by his commands, you are not of God.' 110 As a result of basing assurance on the knowledge of the person and work of Christ, Newton speaks of a growing assurance, growing in proportion to increasing knowledge of Scripture and decreasing self-reliance. He sounds more like one of Bebbington's Puritans than one of his Evangelicals: 'Remember that the progress of faith to assurance is gradual. Expect it not suddenly; but wait upon the Lord for it in the ways of his appointment.'111 At least this Evangelical did not believe assurance to be 'general, normally given at conversion and the result of simple acceptance of the gift of God'.112 With such evidence the picture of a shift from the Puritan view (a late, works-based witness) to the new Evangelical view (an early, direct witness) will not hold. In his work on Newton, Bruce Hindmarsh is also uneasy with the idea of a new Evangelical doctrine of assurance. He quotes Bebbington's characterization and states that 'It would perhaps be well to add that there was a spectrum of opinion on assurance among evangelicals as surely as there was among Puritans.'113 I would go further and aver that there comes a point where the whole idea of a marked distinction between Puritanism and Evangelicalism must be re-examined.

\section{Activism before the 1730s}

Finally, some more general remarks are necessary on the idea of Evangelical activism. As we have seen, Bebbington ties the origins of Evangelicalism to the emergence of activism. This activism was based

110 Works of the Rev. John Newton, 2:599.

111 Works of the Rev. John Newton, 2:598.

112 Evangelicalism in Modern Britain, 43.

113 John Newton and the English Evangelical Tradition (Oxford: Clarendon, 1996), 66. See also 250-56 for a discussion of three letters by Newton which confirm the analysis given here; assurance is traced to the second stage of three in the Christian life, to the wilderness between the exodus and Canaan (Works, $1: 204)$. 
on the Evangelical doctrine of assurance. Given that we find much in the Reformers on assurance that is akin to Bebbington's picture of the Evangelicals, it is odd that he does not trace the emergence of Evangelicalism to the Reformation. The reason is that, though they had the doctrine of assurance, they did not have the activism. The Puritans had neither.114 Such claims highlight the importance of ascertaining exactly what the activism in question entailed. In many of Bebbington's publications he deploys the four characteristics of evangelicalism with a number of examples of each. Detailing some of these examples suggests a wide array of Evangelical activism from across the centuries. In 'The Gospel in the Nineteenth Century' he speaks of preaching, visiting, distributing tracts, prayer meetings, and Sunday schools; in the defining section of Evangelicals in Modern Britain of evangelism, pastoral care, preaching, missionary work, and general philanthropy; in 'Evangelicalism in Modern Britain and America' of missionary activity at home and abroad; in 'Evangelical Christianity and the Enlightenment' of spreading the gospel, philanthropy, and preaching; in 'Revival and Enlightenment in Eighteenth-Century England' of 'spreading the gospel where it was not yet known'; in 'Towards An Evangelical Identity' of a range of activities including evangelism, preaching, missionary work, organized philanthropy, and social reform; and in 'Scottish Cultural Influences on Evangelicalism' principally of the 11,000 visitations made in one year by Thomas Chalmers. ${ }^{115}$

Surely here Bebbington grants too much in his definition of activism. Allowing such breadth to the acceptable types of activity will result in finding the beginning of Evangelicalism not in the Eighteenth but the Sixteenth Century. The Reformers themselves were undeniably activists on these terms. John Calvin and the Huguenots provide an excellent example of the Reformation concern for evangelism. The list drawn up for Admiral de Coligny in 1562 indicates that there were by then 2,150 Huguenot churches in France, and Alister McGrath estimates a total membership above two million

114 'Evangelical Christianity and the Enlightenment', in The Gospel in the Modern World, ed. M. Eden and D.F. Wells (Leicester: IVP, 1991), 66-78 (71).

115 'The Gospel in the Nineteenth century', Vox Evangelica, 13 (1983), 19-28 (22-23); Evangelicals in Modern Britain, 10-12; 'Evangelicalism in Modern Britain and America', 185-86; 'Evangelical Christianity and the Enlightenment', 67; 'Revival and the Enlightenment', 21; 'Towards an Evangelical Identity', in For Such a Time As This, ed. S. Brady \& H. Rowdon (London: Scripture Union, 1996), 37-48 (44-45); 'Scottish Cultural Influences on Evangelicalism', SBET $14: 1$ (1996), 23-36 (23). 
(more than a tenth of the population).116 This was within thirty years of Calvin's own conversion. In England we need only think of a John Bradford preaching in the north of England, or the commonwealth thinkers with leaders such as Hugh Latimer urging practical reform on the young King Edward. Into the Seventeenth Century we find the quest for souls amply represented among the Puritans. Even in a writing which represents the height of John Owen's Reformed Scholasticism, his Dissertation on Divine Justice, we find a conclusion on the uses of the doctrine which directly addresses 'you who live, or rather are dead, under the guilt, dominion, power, and law of sin' and urges self-surrender to Christ. ${ }^{117}$ Richard Baxter held to as complex a theological system as any of the Puritans, but from his work in Kidderminster he could hardly be thought of except as an activist. It is no surprise then that when Bebbington denies the activism of the Puritans he immediately specifies the absence of foreign missions: 'There was, for example, a remarkable absence of Protestant missions in the sixteenth and seventeenth centuries'.118 This is a much tighter definition of activism than he suggests elsewhere, but it is the only one which will sustain his argument. The dating of Evangelicalism to the 1730 s will only work if we say that preaching, pastoring, evangelism and social concern do not count as examples of Evangelical activism. To my mind, and it would seem from his other examples to Bebbington's, that is far too specific, and would be a better designation for a particular expression of Evangelicalism than for the movement per se.

\section{Evangelical Origins and Self-understanding}

If my argument in this paper is correct, then the way is opened to reconsidering the case for the Reformation and Puritanism being authentically Evangelical movements. Whatever differences pertained between the various Evangelical movements would then be understood as differences of accidents rather than substance. This would not be to deny that there were differences. But while they would be significant, they would not be defining, much as Bebbington finds with his account of Evangelical variety yet continuity after the 1730s.

116 A.E. McGrath, A Life of John Calvin (Oxford: Blackwell, 1990), 191-92.

117 Works, 10:620-21.

118 'Evangelical Christianity and the Enlightenment', 71. 
In closing, I wish to step out of the realm of history by commenting briefly on the consequences of this possibility for Evangelical selfunderstanding. If we think that Evangelicalism began in the 1730s, then Wesley and Edwards become its most important fathers. This means that Evangelicalism was from its origin equally divided between Reformed and Arminian theology; neither could claim to be the mainstream doctrinal position. In this sense it is easy to see how Bebbington's analysis serves to give a strong foothold to Arminianism within the Evangelical movement by making foundational one of its most noted proponents. If, however, we reconsider the origins of Evangelicalism and find that it is a Reformational and Puritan phenomenon, then the picture looks very different. The Magisterial Reformers on the Continent and in England during the Sixteenth Century and the Puritans of the Seventeenth were almost without exception committed to a Reformed account of the doctrine of election. Evangelicalism then becomes aboriginally Reformed on the doctrine of election rather than divided. The position taken by John Wesley on election becomes a deviation along with that of Philip Melanchthon and his Lutheran followers, and Jacobus Arminius and the Remonstrants. With such an historical perspective, Reformed theology becomes the authentic Evangelical mainstream of three centuries, and the historical case for the foundational status of Arminianism is undermined. 